\title{
PENERAPAN MODEL PEMBELAJARAN KOPERATIF UNTUK UPAYA MENINGKATKAN PEMAHAMAN PESERTA DIDIK PADA MATERI KASUS-KASUS PELANGGARAN HAK ASASI MANUSIA DALAM PERSPEKTIF PANCASILA
}

\author{
Makbul Muksin \\ SMK Negeri 1 Sakra, Lombok Timur, Nusa Tenggara Barat, Indonesia \\ Email: makbul.muksin@gmail.com
}

Diterima: 02 November 2019, Disetujui: 20 November 2019, Dipublikasikan: 30 November 2019

\begin{abstract}
Abstrak: Penelitian ini bertujuan menggunakan model pembelajaran kooperatif untuk meningkatkan pemahaman peserta didik pada materi kasus-kasus pelanggaran hak asasi manusia dalam perspektif pancasila di kelas XI SMKN 1 Sakra Lombok Timur, Nusa Tenggara Barat. Metode Penelitian Tindakan Kelas yang dilaksanakan pada tahun ajaran 2019/2020 dimana pada penelitian ini menggunakan tiga siklus yang menggunakan sampel peserta didik sebanyak 25 orang. Data hasil penelitian diperoleh melalui tes, observasi dan wawancara. Pemahaman siswa dapat dilihat pada siklus I, nilai peserta didik mencapai nilai rata-rata 60,88. Pada siklus II nilai peserta didik mencapai nilai rata-rata 75,96. Dan pada siklus III nilai peserta didik mencapai nilai rata-rata 82,60. Berdasarkan hasil ini dapat disimpulkan bahwa penerapan model pembelajaran kooperatif pada materi kasus-kasus pelanggaran hak asasi manusia dalam perspektif pancasila efektif dilakukan guna meningkatkan pemahaman peserta didik.
\end{abstract}

Kata kunci: Model Pembelajaran Kooperatif, Pemahaman Peserta Didik, PTK.

\section{PENDAHULUAN}

Pembelajaran merupakan suatu sistem yang terdiri atas komponen yang saling berhubungan satu dengan yang lain yaitu tujuan, materi, metode atau media, dan evaluasi. Penentuan model atau metode pembelajaran oleh guru perlu mempertimbangkan keempat kompoenen tersebut (Sanjaya, 2015; Naway, 2016). Dengan melibatkan keempat kompoenen tersebut makan diharapkan tujuan pembelajaran tidak hanya penguasaan materi pembelajaran, akan tetapi proses untuk mengubah tingkah laku peserta didik menuju lebih baik. Secara umum diarahkan bahwa penguasaan maeri oleh peserta didik dapat dapat mengarahkan membentuk pola prilaku peserta didik itu sendiri (Sudijono, 2013; Sudjana. 2005; Suprihatiningrum, 2013)

Berdasarkan pengamatan guru di kelas XI SMKN 1 Sakra Lombok Timur, Nusa
Tenggara Barat pada materi kasus-kasus pelanggaran hak asasi manusia dalam perspektif pancasila, terdapat berberapa masalah dalam proses pembelajaran. Pertama, masih ditemukan peserta didik tidak focus mengikuti pembelajaran, mereka ribut pada saat KBM berlangsung, peserta didik juga mengobrol dengan teman sebangku dan seringkali tidak mengerjakan tugas. Kedua, peserta didik terlihat pasif, kurang konsentrasi dan kurang aktif dalam kegiatan belajar, kemudian peserta didik malu bertanya menyangkut materi yang diajarkan, bila guru bertanya peserta didik pun tidak menjawab. Hal ini menyebabkan banyak peserta didik kesulitan mencapai KKM pada mata pelajaran PPKn.

Berdasarkan maslaah tersebut maka kami menerapkan solusi yaitu model pembelajaran kooperatof. Pembelajaran koperatif dapat meningkatkan pemahaman siswa dan hasil belajar (Tuken, 2016; 
Cahyani, 2015). Maka dari itu melalui penggunaan metode koperatif ini diharapkan peserta didik mampu meningkatkan pemahaman peserta didik terhadap pembelajaran PPKn pada materi kasus-kasus pelanggaran hak asasi manusia dalam perspektif pancasila. Berdasarkan latar belakang masalah tersebut di atas, maka telah dilakukan Penelitian Tindakan Kelas dengan melakukan tiga siklus dengan penerapan model koperatif dalam upaya peningkatan pemahamana konsep siswa di kelas XI SMKN 1 Sakra Lombok Timur, Nusa Tenggara Barat pada materi kasus-kasus pelanggaran hak asasi manusia dalam perspektif pancasila.

\section{METODE}

Metode penelitian ini adalah penelitian tindakan kelas dengan penerapan model koperatif sebagai upaya meningkatkan pemahaman peserta didik pada materi kasus-kasus pelanggaran hak asasi manusia dalam perspektif pancasila. Langkah-langkah penelitian yang dilakukan terbagi kedalam bentuk siklus dimana setiap siklus terdiri dari empat kegiatan. Siklus pertama, siklus kedua, maupun siklus ketiga dalam PTK ini terdiri dari perencanaan, pelaksanaan, pengamatan dan refleksi. Data hasil belajar dikumpulkan untuk setiap siklus. Adapun teknik pengumpulan data yang digunakan untuk mendapatkan data penelitian dengan cara tes, wawancara, observasi dan studi dokumentasi.

\section{HASIL DAN PEMBAHASAN}

Berdasarkan kedua Tabel 1 dan 2 menujukkan bahwa upaya meningkatkan pemahaman peserta didik pada materi kasuskasus pelanggaran hak asasi manusia dalam perspektif pancasila melalui metode pembeljaran koperatif lebih mudah dipahami bagi peserta didik kelas peserta didik kelas XI di SMKN 1 Sakra Lombok Timur, Nusa Tenggara Barat.

Tabel 1. Peningkatan Hasil Belajar Peserta didik Siklus I,II dan III

\begin{tabular}{lclll}
\hline Siklus & $\begin{array}{c}\text { Jumlah } \\
\text { Responden }\end{array}$ & Rata-rata & Peningkatan (\%) & Keputusan \\
\hline I & 25 & 60,88 & $39 \%$ & Belum Tercapai \\
II & 25 & 75,96 & $86 \%$ & Sudah Tercapai \\
III & 25 & 82,60 & $100 \%$ & Sudah Tercapai \\
\hline
\end{tabular}

Tabel 2. Rekapitulasi Hasil Belajar Peserta Didik Siklus I, II dan III

\begin{tabular}{llll}
\hline Kriteria & Siklus I & Siklus II & Siklus III \\
\hline Jumlah nilai & 1630 & 1810 & 1945 \\
Rata-rata ketercapaian & 60,88 & 75,96 & 82,60 \\
Jumlah peserta didik tuntas & 10 & 21 & 25 \\
Jumlah peserta didik tidak tuntas & 15 & 4 & 0 \\
Jumlah peserta didik tuntas (\%) & $39 \%$ & $86 \%$ & $100 \%$ \\
Jumlah peserta didik tidak tuntas (\%) & $61 \%$ & $14 \%$ & 0 \\
\hline
\end{tabular}

Model koperatif diterapkan pada Penelitian Tindakan Kelas pada pembelajaran PPKn kelas XI di SMKN 1 Sakra Lombok Timur, Nusa Tenggara Barat pada materi Kasus-kasus pelanggran hak asasi manusia dalam perspektif pancasila. Peneilitian ini mengambil data dan menyimpulkan data yang diperoleh dnegan membahas hasil test evaluasi, hasil observasi, wawancara, catatan lapangan dan refleksi dari variabel peneliti. Hasil belajar adalah variable utama yang diujikan pada penelitian ini, dimana peserta didik mengalami perlakukan siklus pembelajaran dan hasil siklus dan hasil observasi kegiatan belajar mengajar. Pada setiap siklus dilakukan perbaikan penelitian tindakan yang dilakukan, upaya ini terus dilakukan hingga semua siswa mencapai ketuntasan maksimal.

Pada tahapan siklus I, pemahaman peserta didik belum tampak dimana peserta didik masih terlihat tidak aktif dan suasana dalam kelas tidak kondusif. Hal ini karena kemungkinan peserta didik belum terbiasa dengan model yang 
diterapkan dan belum paham terhadap tugas yang harus dikerjakan akibatnya suasana kelas menjadi ribut. Pada siklus ini, kolabolator ahli memberikan masukan kepada peneliti agar memberikan penjelasan materi dengan lebih menarik dan diberikan secara ringan agar tercapainya hasil belajar yang cukup baik pada tahapan berikutnya.

Pada tahapan siklus II, sudah mulai adanya tampak peningkatan pembelajaran dengan menggunakan metode koperatif. Hal ini dapat dilihat dari Tabel 2 dimana terjadi peningkatan hasil belajar. Terlihat kegiatan peserta didik mulai kondusif pada siklus II dan banyak peserta didik yang memperhatikan pembelajaran yang cukup baik karena adanya antusian peserta didik dalam menerima pembelajaran. Pada siklus ini kolabolator menyarankan agar peneliti lebih focus pada beberapa speserta didik yang belum bisa mengikuti ritme teman mereka yang lain. Hal in perlu dilakukan agar semua peserta didik menjadi focus dan berkonsentrasi pada pembelajaran yang dilakukan.

Tabel 1 dan 2 menujukkan perubahan yang sangat baik pada siklus III. Pesreta didik mulai penyelesaian tugas tugas yang diberikan dan terlihat peserta didik mulai aktif dalam mengikuti diskusi kelompok yang dilakukan. Tidak terlihat dominasi individu yang terlalu berlebihan pada satu kelompok. Secara umum tampak bahwa hasil belajar mengalami peningkatan pada setiap siklusnya. Hasil ini selaras dengan beberapa penelitian sebelumnya (Sulasti, 2013; Kurnia, 2013). Berdasarkan hasil pengamatan atau observasi, dokumentasi dan pelaksanaan setiap siklus menunjukan bahawa penelitian tindakan kelas dengan penerapan model koperatif dapat memberikan hasil sesuai yang diharapkan terhadap peningkatan pemahaman peserta didik kelas.

\section{KESIMPULAN}

Telah dilajukan penelitian tindakan kelas dengan penerapan model pembelajaran koperatif pada pembelajaran PPKn materi Kasus-kasus pelanggran hak asasi manusia dalam perspektif pancasila di kelas XI di SMKN 1 Sakra Lombok Timur, Nusa Tenggara Barat. Berdasrakan hasil observasi dan data yang diperoleh peningkatan =variable hasil belajar peserta didik pada setiap siklus pembelajaran. Suasana belajar mulai meningkat kondusif, siswa lebih aktif, adanya motivasi, dan peserta didik lebih berani dalam bertanya maupun menjawab pertanyaan yang diberikan oleh guru dalam proses pembelajaran. Oleh sebab itu dapat disimpulkan bahwa penerapan model koperatif mampu meningkatkan pemahaman siswa pada materi kasus-kasus pelanggaran hak asasi manusia dalam perspektif pancasila.

\section{REFERENSI}

Cahyani, I. Gusti Agung Ayu Novia, I. Made Tegeh, and I. Komang Sudarma (2015). "Pengaruh model pembelajaran kooperatif tipe stad berbantuan multimedia pembelajaran terhadap hasil belajar pkn." Jurnal Edutech Undiksha, 3 (1).

Kurnia, I. (2013). Penerapan Model Pembelajaran Kooperatif Tipe Snowball Throwing untuk Meningkatkan Hasil Belajar PKN. Journal of Elementary Education, 2(2).

Naway, Fory A (2016). "Strategi Pengelolaan Pembelajaran." Gorontalo: Ideas Publishing.

Sudijono, A. (2008). Pengantar Evaluasi Pendidikan. Jakarta: Raja Grafindo Persada.

Sudjana, N. (2005). Dasar-Dasar Proses Belajar Mengajar. Bandung: Sinar Baru Aldesindo.

Sulasti, N. W. (2013). Penerapan model pembelajaran kooperatif tipe Group Investigation (GI) untuk meningkatkan aktivitas dan hasil belajar siswa dalam pelajaran PKn di kelas XI IPA 1 SMA Negeri 1 Sawan tahun ajaran 2012/2013. Jurnal Pendidikan Kewarganegaraan Undiksha, 2(1).

Suprihatiningrum, J. (2013). Strategi Pembelajaran Teori dan Aplikasi. Jogjakarta: Ar-Ruzz Media.

Tuken, R. (2016). Peningkatan Hasil Belajar Siswa pada Mata Pelajaran Pkn Melalui Pembelajaran Kooperatif tipe Role Playing di Kelas VI SDN IV Kota Parepare. Publikasi Pendidikan, 6(2). 